\title{
GAMBARAN AWAL EFEK SAMPING VAKSIN SINOVAC-CORONAVAC PADA PETUGAS KESEHATAN DI KABUPATEN KEPULAUAN SANGIHE
}

\author{
PRELIMINARY DATA ON SINOVAC-CORONAVAC VACCINE'S SIDE EFFECTS AMONG \\ HEALTHWORKER IN SANGIHE ISLAND DISTRICT
}

\author{
Chandrayani Simanjorang, Conny Juliana Surudani, Yenny Budiman Makahaghi \\ Program Studi Keperawatan, Politeknik Negeri Nusa Utara \\ Email: simanjorangyani@gmail.com
}

\begin{abstract}
Abstrak: Efek samping vaksin COVID-19 menjadi informasi yang sangat penting diketahui untuk meyakinkan masyarakat dalam rangka peningkatan cakupan vaksinasi. Penelitian ini bertujuan melakukan studi independen untuk mengetahui efek samping Sinovac-CoronaVac pada petugas kesehatan. Metode penelitian berupa cross-sectional pada Juni-Desember 2021. Kuesioner berisi pertanyaan tentang data demografi, anamnesis, dan efek samping vaksin Mayoritas partisipan tidak merasakan efek samping apapun, 61,8\% setelah dosis 1 dan $88,1 \%$ setelah dosis 2. Efek samping yang dirasakan umumnya ringan seperti mengantuk $(14,7 \%)$, tidak enak badan $(6,5 \%)$, sakit di lokasi suntikan $(4,8 \%)$, sakit kepala $(5,8 \%)$, demam $(5,1 \%)$, nafsu makan meningkat $(3,8 \%)$, letih/lesu $(3,1 \%)$, bengkak di lokasi suntikan $(2,4 \%)$, dan nyeri ulu hati $(0,7 \%)$. Terdapat perbedaan proporsi efek samping yang signifikan menurut kelompok umur dan riwayat alergi. Efek samping vaksin Sinovac-CoronaVac tergolong ringan bahkan tanpa efek samping, sehingga masyarakat tidak perlu ragu untuk mendapatkan vaksinasi COVID-19.
\end{abstract}

Kata kunci: efek samping, Sinovac-CoronaVac, vaksin, COVID-19

\begin{abstract}
The study of COVID-19 vaccine side effects is very important to convince the community to increase vaccination coverage. This study aimed to conduct an independent study to determine the side effects of Sinovac-CoronaVac among health workers. The cross-sectional research method was carried out in June-December 2021 on health workers. The questionnaire contains questions about demographic data, medical anamneses, and vaccine side effects. The majority of participants did not feel any side effects, $61.8 \%$ after dose 1 and $88.1 \%$ after dose 2. The side effects felt were generally mild, including increased sleep (14.7\%), feeling unwell $(6.5 \%)$, injection site pain (4.8\%), headache (5.8\%), fever (5.1\%), increased appetite (3.8\%), fatigue (3.1\%), injection site swelling (2.4\%), and nausea (0.7\%). There was a significant difference in the proportion of side effects according to age group and allergy history. The side effects of the Sinovac-CoronaVac vaccine are mild and even without side effects, so people don't need to hesitate to get the COVID-19 vaccination.
\end{abstract}

Keyword: The side effects, Sinovac-CoronaVac, vaccine, COVID-19

\section{PENDAHULUAN}

Pandemi Corona Virus Desease 2019 (COVID-19) di Indonesia masih terus berlanjut. Pemberian vaksin diharapkan dapat menjadi salah satu upaya untuk mengendalikan penularannya. Proses pemberian vaksin tahap pertama dijadwakan pada Januari-April 2021 yaitu kepada petugas kesehatan, asisten tenaga kesehatan, tenaga penunjang serta mahasiswa yang sedang menjalani pendidikan profesi kedokteran yang bekerja pada Fasilitas Pelayanan Kesehatan. Selanjutnya para pelayan publik dan kelompok usia lanjut ( $\geq 60$ tahun). Tahap terakhir atau tahap 4 adalah pemberian vaksin bagi masyarakat umum (April 2021-Maret 2022). (Kementrian Kesehatan RI, 2021).

Menurut data Dinas Kesehatan Kabupaten Kepulauan Sangihe, di pertengahan Februari 2021 kurang lebih 949 petugas kesehatan telah melakukan 
vaksinasi COVID-19. Bagaimana efek samping dari proses vaksinasi tersebut belum diketahui. Pada uji klinis fase 3 telah dilaporkan bahwa efek samping vaksin di Indonesia rata-rata ringan maupun sedang. (Komnas KIPI Indonesia, 2021). Di Israel ditemukan 22 orang petugas kesehatan terinfeksi COVID-19 setelah disuntik vaksin COVID-19. (Amit et al., 2021). Sementara di Indonesia terdapat 2 orang tenaga kesehatan yang meninggal karena COVID-19 padahal sudah disuntik vaksin. Menurut komnas KIPI (2021) hal ini kemungkinan disebabkan oleh kekebalan yang belum terbentuk di awal vaksinasi. Gambaran sesungguhnya di lapangan perlu dinilai agar dapat dijadikan acuan ataupun evaluasi dari proses vaksinasi. Selain itu studi mengenai efek samping vaksin COVID-19 pada petugas kesehatan memiliki potensi besar untuk meningkatkan kepercayaan masyarakat terhadap vaksin sehingga dapat meningkatkan cakupannya. Cakupan yang tinggi akan mempercepat tercapainya kekebalan kelompok/herd immunity. Oleh karena itu, penelitian ini bertujuan untuk mengetahui gambaran efek samping atau kejadian ikutan pasca imunisasi (KIPI) vaksin COVID-19 pada petugas kesehatan yang sudah mendapatkan suntikan vaksin dosis 1 dan 2 .

\section{METODE PENELITIAN}

Metode penelitian menggunakan crosssectional method dengan teknik pengumpulkan data secara retrospektif menggunakan kuesioner/form. Setiap partisipan yang sudah menyatakan kesediaannya akan mengisi form/kuesioner secara mandiri. Pengambilan data dilakukan pada Juni-Desember 2021. Kriteria dalam penelitian ini adalah petugas kesehatan WHO mengeluarkan rekomendasi penggunaan vaksin Sinovac-CoronaVac pada Mei 2021. Vaksin Sinovac-CoronaVac merupakan vaksin yang terbuat dari virus SARS-CoV-2 yang telah dilemahkan (inactivated) untuk memicu imun. Vaksin ini diberikan kepada populasi dengan usia 18 tahun ke atas sebanyak 2 dosis $(0,5 \mathrm{ml})$, dengan interval dosis 1 dan 2 selama 2-4 minggu. Setiap $0.5 \mathrm{ml}$ vaksin terdiri yang berkerja di Kabupaten Kepulauan Sangihe serta mendapat vaksin COVID-19 dosis 1 dan 2 .

Data yang dikumpulkan merupakan data primer. Kuesioner yang disusun diadaptasi dari Formulir Pelaporan KIPI Serius dan Format Investigasi Kementrian Kesehatan (2021). Kuesioner berisi pertanyaan tentang data demografi, anamnesis, dan efek samping vaksin.

Perhitungan sampel menggunakan rumus besar sampel estimasi proporsi presisi absolut yaitu $n=Z_{1-\alpha / 2}^{2}$ $\mathrm{P}(1-\mathrm{P}) / \mathrm{d}^{2}$. Dimana nilai $\mathrm{P}$ merupakan proporsi penerima vaksin yang mengalami efek samping ringan. Nilai $\mathrm{P}$ diambil dari penelitian sebelumnya yaitu efek samping vaksin Pfizer $84.7 \%$ kategori ringan (Centers for Disease Control and Prevention, 2021). Nilai d merupakan simpangan baku yang dapat diterima adalah $5 \%(\mathrm{~d}=0,05)$. Derajat kepercayaan 95\% $(\mathrm{Z} \alpha=1.96)$. Maka total nilai minimal sampel $\mathrm{N}=196$ sampel. Teknik pengambilan sampel menggunakan non probability sampling. Sementara untuk analisis data menggunakan SPSS 21.0. Data deskriptif (kontinyu) akan disajikan dalam bentuk mean \pm standard deviation (SD) dan variabel kategorik dalam bentuk persentase atau grafik.

Protokol studi telah mendapat persetujuan dari Komisi Etik Peneltian Kesehatan Politeknik Negeri Manado (KEPK.01/07/181/2021). Seluruh partisipan diminta persetujuannya untuk menjadi partisipan dengan menandatangani inform consent. Informasi terkait data individu dijaga kerasahasiaannya oleh peneliti.

\section{HASIL DAN PEMBAHASAN}

dari $3 \mu \mathrm{g}$ virus SARS-CoV-2 yang tidak aktif. Eksipiennya adalah aluminium hidroksida, dinatrium WHO mengeluarkan rekomendasi penggunaan vaksin Sinovac-CoronaVac pada Mei 2021. Vaksin SinovacCoronaVac merupakan vaksin yang terbuat dari virus SARS-CoV-2 yang telah dilemahkan (inactivated) untuk memicu imun. Vaksin ini diberikan kepada populasi dengan usia 18 tahun ke atas sebanyak 2 dosis 
(0,5 ml), dengan interval dosis 1 dan 2 selama 2-4 minggu. Setiap $0.5 \mathrm{ml}$ vaksin terdiri dari $3 \mu \mathrm{g}$ virus SARS-CoV-2 yang tidak aktif. Eksipiennya adalah aluminium hidroksida, hidrogen fosfat, natrium dihidrogen fosfat, natrium klorida, dan air untuk injeksi (WHO, 2021). Efikasi vaksin Sinovac-CoronaVac sebesar $51 \%$ dapat mencegah infeksi SARS-COV-2, $100 \%$ mencegah keparahan, dan $100 \%$ mencegah hospitalisasi 2 minggu setelah menerima dosis kedua (WHO, 2021). Vaksin Sinovac-CoronaVac ini merupakan platform vaksin yang digunakan untuk petugas kesehatan di Kabupaten Kepulauan Sangihe.

Total partisipan (petugas kesehatan) yang mengisi kuesioner sebanyak 297 orang. Terdapat 4 orang yang tidak memenuhi kriteria inkusi sehingga tidak dimasukkan dalam analisis. Seluruh partisipan mendapatkan vaksin Sinovac-CoronaVac dosis 1 dan 2 dengan nomor bacth 202011047. Vaksinasi dilaksanakan pada Februari-Maret 2021 dimana jarak waktu dosis pertama dan kedua rata-rata 2 minggu.

Table 1. Karakteristik demografi petugas kesehatan yang divaksin Sinovac-CoronaVac

\begin{tabular}{|c|c|c|}
\hline Karakteristik Demografi & Jumlah & Persentase \\
\hline \multicolumn{3}{|l|}{ Profesi } \\
\hline Dokter & 11 & $3,8 \%$ \\
\hline Perawat & 252 & $86,0 \%$ \\
\hline Bidan & 25 & $8,5 \%$ \\
\hline Analis & 1 & $0,3 \%$ \\
\hline Ahli Gizi & 3 & $1,0 \%$ \\
\hline Kesling & 1 & $0,3 \%$ \\
\hline \multicolumn{3}{|l|}{ Usia } \\
\hline$\leq 34$ tahun & 169 & $57,7 \%$ \\
\hline$>34$ tahun & 124 & $42,3 \%$ \\
\hline \multicolumn{3}{|l|}{ Tempat tinggal (kecamatan) } \\
\hline Kendahe & 20 & $6,8 \%$ \\
\hline Manganitu & 49 & $16,7 \%$ \\
\hline Manganitu Selatan & 1 & $0,3 \%$ \\
\hline Tabukan Selatan & 2 & $0,7 \%$ \\
\hline Tabukan Tengah & 18 & $6,1 \%$ \\
\hline Tabukan Utara & 40 & $13,7 \%$ \\
\hline Tahuna & 74 & $25,3 \%$ \\
\hline Tahuna Barat & 35 & $11.9 \%$ \\
\hline Tahuna Timur & 50 & $17,1 \%$ \\
\hline Tamako & 4 & $1,4 \%$ \\
\hline \multicolumn{3}{|l|}{ Tempat Vaksinasi } \\
\hline Puskesmas & 168 & $57,3 \%$ \\
\hline Rumah Sakit & 124 & $42,3 \%$ \\
\hline Rumah Penduduk & 1 & $0,3 \%$ \\
\hline \multicolumn{3}{|l|}{ Kondisi sebelum vaksin } \\
\hline Sehat & 266 & $90,8 \%$ \\
\hline Hipertensi/DM/TBC/Asma/Lainnya & 27 & $9,2 \%$ \\
\hline \multicolumn{3}{|l|}{ Riwayat alergi } \\
\hline Ada riwayat & 38 & $13,0 \%$ \\
\hline Tidak ada riwayat & 255 & $87,0 \%$ \\
\hline
\end{tabular}


Dari total 293 partisipan yang masuk dalam analisis berprofesi sebagai dokter, perawat, bidan, analis (petugas laboratorium), ahli gizi, dan staf kesehatan lingkungan. Mayoritas partisipan berprofesi sebagai perawat (86\%). Jika dilihat dari kelompok usia, proporsi antara usia $\leq 34$ tahun hampir sama dengan kelompok usia > 34 tahun $(57,7 \%$ dan $42,3 \%)$. Rentang usia partisipan antara 20-59 tahun. Mayoritas partisipan bertempat tinggal di Tahuna $(25,3 \%)$, vaksinasi di lakukan di Puskesmas $(57,3 \%)$, kondisi partisipan sebelum vaksinasi sehat $(90,8 \%)$, dan tidak memiliki riwayat alergi sebesar $87 \%$ (Tabel 1).

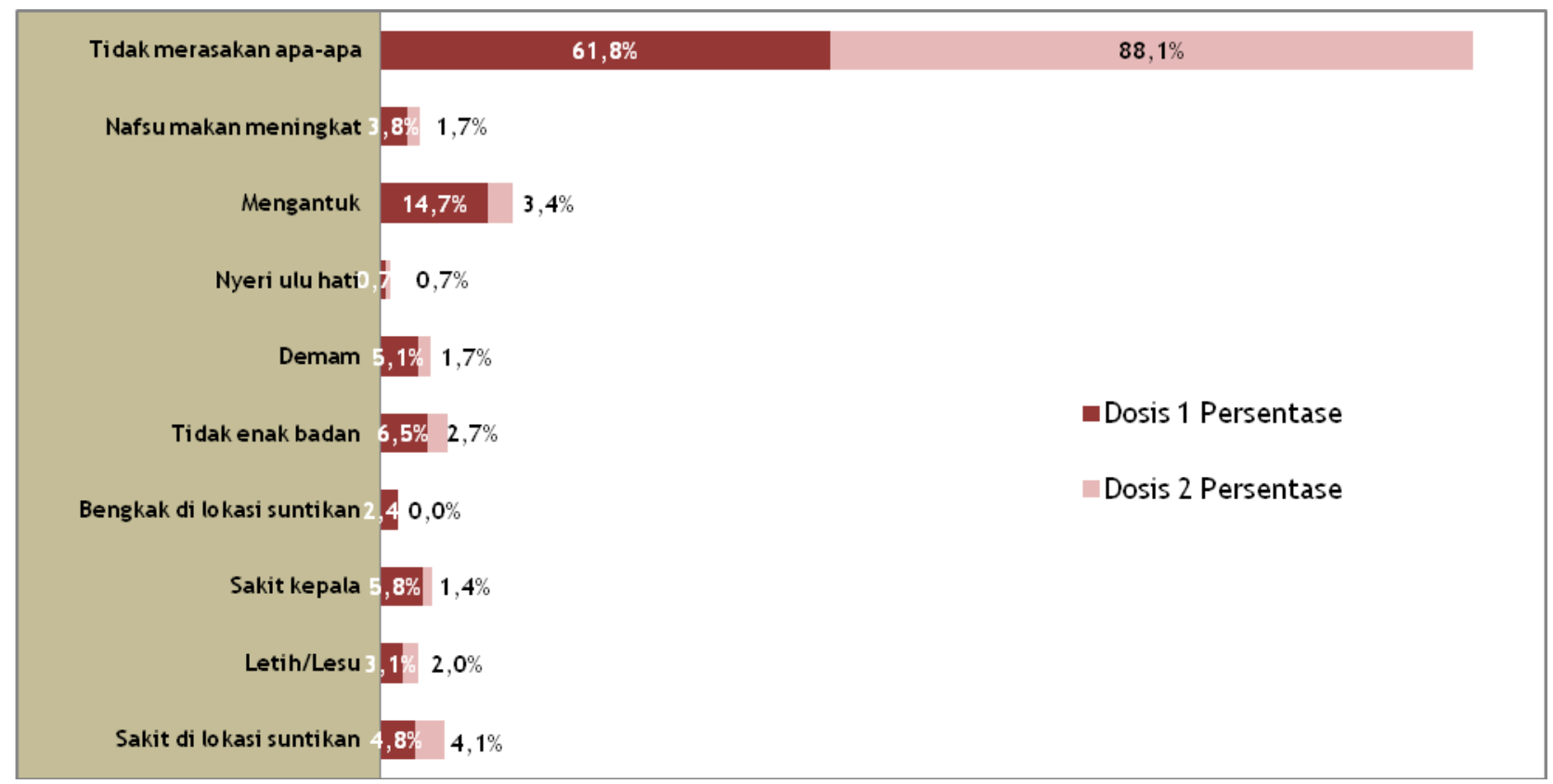

Grafik 1. Efek Samping Vaksin Sinovac-CoronaVac pada Petugas Kesehatan $\leq 7$ Hari Setelah Dosis1 dan Dosis 2

Berdasarkan grafik 1 mayoritas partisipan tidak mengalami efek samping apapun untuk dosis pertama $(61.8 \%)$ dan dosis kedua $(88.1 \%)$. Sebagian kecil mengalami efek samping seperti mengantuk, tidak enak badan, sakit di lokasi suntikan, sakit kepala, demam, nafsu makan meningkat, letih/lesu, bengkak di lokasi suntikan, dan nyeri ulu hati. Jika dilihat secara keseluruhan proporsi efek samping lebih tinggi pada dosis 1 daripada dosis 2, sedangkan proporsi partisipan yang tidak mengalami efek samping meningkat setelah dosis ke-2 (Grafik 1). Proporsi efek samping dalam penelitian ini lebih rendah dibandingkan dengan hasil uji klinis fase 3 vaksin Sinovac-CoronaVac yaitu sakit di lokasi suntikan sebesar 39,6\% dan sakit kepala $24,2 \%$ setelah dosis 1 . Sakit di lokasi suntikan $24,1 \%$ dan sakit kepala 24,6\% setelah dosis 2. (WHO, 2021)
Begitu juga dengan hasil uji klinis vaksin Janssen untuk usia 18-59 tahun yang proporsi efek sampingnya lebih tinggi, yaitu reaksi lokal yang muncul diantaranya sakit di lokasi suntikan $(58,6 \%)$, bengkak $(7 \%)$. Sementara reaksi sistemik seperti demam $(12,8 \%)$, sakit kepala $(44,4 \%)$, letih/lesu $(43,8 \%)$, nyeri otot $(39,1 \%)$, nausea $(15,5 \%)$. (Centers for Disease Control and Prevention, 2021). Demikian juga vaksin Pfizer-BioNTech efek samping yang dilaporkan adalah sakit di lokasi suntikan (89.8\%), letih/lesu (62.2\%), sakit kepala $(45.6 \%)$, nyeri otot (37.1\%), and menggigil (33.9\%). ( $\operatorname{Riad~A,~et~al.,~2021).~}$ Secara keseluruhan efek samping vaksin SinovaCoronaVac pada penelitian ini, baik rekasi lokal maupun sistemik, lebih sedikit dibandingkan dengan vaksin Janssen dan Pfizer-BioNTech. Sejalan dengan 
penelitian sebelumnya yang menemukan bahwa efek samping lokal dan sistemik pada inactivated vaksin (Sinova-CoronaVac) lebih rendah dibandingkan dengan platform RNA vaksin seperti Pfizer-BioNTech dan platform Non-Replicating Viral Vector seperti Janssen. (Wu et al, 2021).

Terdapat efek samping lainnya yang tidak masuk dalam daftar hasil uji klinis yaitu mengantuk $14,7 \%$ dan nafsu makan meningkat 3,8\% setelah dosis 1. Proporsi ini mengalami penurunan setelah dosis ke-2 yaitu $3,4 \%$ dan $1,7 \%$. Efek samping tersebut tentu saja tidak berbahaya serta tidak menimbulkan rasa sakit. Penelitian sebelumnya terkait efek samping vaksin BNT162b2 mRNA juga menemukan proporsi mengantuk sebesar 2,12\% dan selera makan yang meningkat sebesar 0,87\%. (Kadali et al., 2021). Beberapa ahli menjelaskan mengapa seseorang merasakan kantuk dan lapar setelah vaksinasi kemungkinan disebabkan pengeluaran energi oleh tubuh dalam pembentukan antibodi. Energi yang terkuras menyebabkan kantuk dan rasa lapar. (CNN, 2021)

Tabel 2. Hubungan Usia, Riwayat Alergi, dan Riwayat Penyakit dengan Efek Samping Vaksin Sinovac-CoronaVac $\leq 7$ Hari Setelah Dosis 1 dan Dosis 2

\begin{tabular}{|c|c|c|c|c|c|c|}
\hline \multirow{2}{*}{ Variabel } & \multicolumn{2}{|c|}{ Efek Samping Dosis 1} & \multirow{2}{*}{$\begin{array}{c}P \text { - } \\
\text { value }^{*}\end{array}$} & \multicolumn{2}{|c|}{ Efek Samping Dosis 1} & \multirow{2}{*}{$P$-value } \\
\hline & Ada & Tidak ada & & Ada & Tidak ada & \\
\hline \multicolumn{7}{|l|}{ Usia } \\
\hline$\leq 34$ tahun & $76(67,3 \%)$ & $93(51,7 \%)$ & \multirow{2}{*}{$\mathbf{0 , 0 1 2}$} & $23(65,7 \%)$ & $146(56,6 \%)$ & \multirow{2}{*}{0,305} \\
\hline$>34$ tahun & $37(32,7 \%)$ & $87(48,3 \%)$ & & $12(34,3 \%)$ & $112(43,4 \%)$ & \\
\hline \multicolumn{7}{|l|}{ Riwayat alergi } \\
\hline Ada riwayat & $24(21,2 \%)$ & $14(7,8 \%)$ & \multirow{2}{*}{0,001} & $5(14,3 \%)$ & $33(12,8 \%)$ & \multirow{2}{*}{0,805} \\
\hline Tidak ada riwayat & $89(78,8 \%)$ & $166(92,2 \%)$ & & $30(85,7 \%)$ & $225(87,2 \%)$ & \\
\hline \multicolumn{7}{|l|}{ Riwayat penyakit } \\
\hline Ada riwayat & $13(11,5 \%)$ & $14(7,8 \%)$ & \multirow{2}{*}{0,283} & $4(11,4 \%)$ & $23(8,9 \%)$ & \multirow{2}{*}{0,545} \\
\hline Tidak ada riwayat & $100(88,5 \%)$ & $166(92,2 \%)$ & & $31(88,6 \%)$ & $235(91,1)$ & \\
\hline
\end{tabular}

*Chi-square test dengan level signifikan $<0,05$

Berdasarkan Tabel 2, terdapat perbedaan proporsi yang signifikan efek samping dosis 1 pada kelompok usia $\leq 34$ tahun dengan kelompok usia $>34$ tahun. Demikian juga riwayat alergi, terdapat perbedaan proporsi efek samping yang signifikan antara kelompok yang memiliki riwayat alergi dengan kelompok yang tidak memiliki riwayat alergi. Penelian sebelumnya juga menemukan bahwa terdapat perbedaan proporsi efek samping yang signifikan antara golongan umur $\leq 43$ tahun dengan kelompok usia $>43$ tahun. Namun tidak terdapat pebedaan yang signifikan pada variabel riwayat alergi. (Riad et al., 2021). Dengan demikian dibutuhkan penelitian lebih lanjut terkait hubungan riwayat alergi dengan efek samping vaksinasi. Karena ditemukan reaksi alergi pada uji klinis meskipun tidak besar proporsinya (0,3\%). (WHO, 2021).
Jika dilihat secara keseluruhan, proporsi efek samping setelah dosis 2 lebih rendah dibandingkan dengan dosis 1 . Hasil penelitian ini berbeda dengan hasil uji klinis sebelumnya dimana efek samping dosis 2 biasanya lebih terasa. Perbedaan ini kemungkinan dapat disebabkan karena mayoritas efek samping yang dialami partisipan pada penelitian ini adalah reaksi lokal dan bukan reaksi sistemik. Reaksi lokal pada lokasi suntikan menjadi lebih ringan pada suntikan ke2.

Hasil penelitian juga menunjukkan bahwa tidak terdapat hubungan antara riwayat penyakit dengan kejadian efek samping vaksin Sinovac-CoronaVac baik dosis 1 maupun dosis 2 (Tabel 2). Hasil tersebut sejalan dengan hasil uji klinis yang didokumentasikan oleh WHO tahun 2021 dimana vaksin SinovacCoronaVac buatan China ini tidak memiliki risiko pada populasi penderita hipertensi, obesitas, dan diabetes 
melitus. Sementara beberapa penelitian sebelumnya menemukan bahwa komorbiditas (penyakit penyerta) seperti hipertensi dan diabetes melitus menjadi faktor risiko keparahan dan kematian pasien COVID-19 (McKeigue et al., 2020; McKurnaghan et al., 2021; Wang et 1., 2021). Oleh karena itu populasi berisiko dengan komorbiditas hipertensi atau diabetes melitus dapat dijadikan sebagai kelompok prioritas vaksinasi. Namun demikian, dibutuhkan penelitian lebih lanjut untuk mengetahui pengaruh variabel masing-masing riwayat penyakit terhadap efek samping vaksinasi (multivariate), karena penilaian hubungan pada penelitian ini hanya berdasarkan perbedaan proporsi (bivariate).

Interpretasi hasil penelitian ini terbatas pada populasi petugas kesehatan di Kabupaten Kepulauan Sangihe. Teknik pemilihan sampel yang tidak random dapat menyebabkan bias seleksi dimana hanya petugas kesehatan yang memiliki antusias tinggi yang berpartisipasi mengisi kuesioner. Sejauh pengetahuan

\section{DAFTAR RUJUKAN}

Amit, S. et al., 2021. Postvaccination COVID-19 among Healthcare Workers, Israel. Center for Disease Control and Prevention, (online), Volume 27, No. 4, https://wwwnc.cdc.gov/eid/article/27/4/210016_article

Centers for Disease Control and Prevention (CDC). 2021. The Janssen COVID-19 Vaccine's Local Reactions, Systemic Reactions, Adverse Events, and Serious Adverse Events. (Online), https://www.cdc.gov/vaccines/covid-19/infoby-product/janssen/reactogenicity.html

Centers for Disease Control and Prevention (CDC). 2021. Local Reactions, Systemic Reactions, Adverse Events, and Serious Adverse Events: Pfizer-BioNTech COVID-19 Vaccine. (online), https://www.cdc.gov/vaccines/covid-19/infoby-product/pfizer/reactogenicity.html

CNN Indonesia. 25 Maret 2021. Alasan Mengantuk Usai Vaksinasi Covid-19. (online), https://www.cnnindonesia.com/gayahidup/20190513112146-255-394337/alasan- peneliti, penelitian ini adalah yang pertama dilakukan di Indonesia untuk mendapatkan gambaran efek samping vaksin Sinovac-CoronaVac pada petugas kesehatan dengan nomor bacth 202011047.

\section{KESIMPULAN}

Efek samping vaksin Sinovac-CoronaVac tergolong ringan bahkan mayoritas partisipan tidak mengalami efek samping sama sekali. Jenis efek samping yang dialami diantaranya mengantuk, mengantuk, tidak enak badan, demam, sakit di lokasi suntikan, sakit kepala, nafsu makan meningkat, letih/lesu, nyeri ulu hati. Studi lebih lanjut diperlukan dengan memperluas populasi penelitian dan menambahkan jenis-jenis vaksin lainnya untuk mengetahui efek samping secara keseluruhan pada populasi umum sehingga kepercayaan masyarakat terhadap vaksin meningkat. Dengan meningkatnya kepercayaan masyarakat maka kesadaran untuk mendatangi pos-pos vaksin yang disediakan oleh pemerintah semakin meningkat juga.

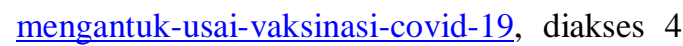
Oktober 2021

Kadali RAK, et al. 2021. Side effects of BNT162b2 mRNA COVID-19 vaccine: A randomized,cross-sectional study with detailed self-reported symptoms fromhealthcare workers. International Journal of Infectious Diseases, 106:376-381. https://doi.org/10.1016/j.ijid.2021.04.047

Kementrian Kesehatan RI. 2021. Petunjuk Teknis Pelaksanaan Vaksinasi dalam Rangka Penanggulangan Pandemi Corona Virus Disease 2019 (COVID-19). [Accessed February 20, 2021]. Available from: Final SK Dirjen Juknis Vaksinasi COVID-19 02022021.pdf (kemkes.go.id)

Komnas KIPI Indonesia._2021. Komnas KIPI: Sejauh Ini, Semua Laporan KIPI Bersifat Ringan. Diakses dari Komnas KIPI: Sejauh Ini, Semua Laporan KIPI Bersifat Ringan - Berita Terkini 
COVID19.go.id. 24 Februari 2021

LaMorte WW. Sample Sizes for Two Independent Samples, Continuous Outcome. 2020. Boston University School of Public Health.

Lemeshow S, David H., Klar J. (1990). Adequacy of Sample Size in Helath Studies. 1990. Yogyakarta: Gajah Mada University Press.

McGurnaghan SJ, et al. 2021. Risks of and risk factors for COVID-19 disease in people with diabetes: a cohort study of the total population of Scotland. The Lancet, 9(2):82-93. https://doi.org/10.1016/S2213-8587(20)304058

McKeigue PM, et al. 2020. Rapid Epidemiological Analysis of Comorbidities and Treatments as risk factors for COVID-19 in Scotland (REACT-SCOT): A population-based casecontrol study. PLoS Med, 17(10): e1003374. https://doi.org/10.1371/journal.pmed.1003374

Riad A. et al. 2021. Prevalence of COVID-19 Vaccine Side Effects among Healthcare Workers in the
Czech Republic. J. Clin. Med, 10(7):1428. https://doi.org/10.3390/jcm10071428

Wang X. et al. 2021. Risk Factors for COVID-19 in Patients with Hypertension. Hindawi, 2021: 19. https://doi.org/10.1155/2021/5515941

WHO. 2021. Interim recommendations for use of the inactivated COVID-19 vaccine, CoronaVac, developed by Sinovac-CoronaVac. Genewa, (online),

https://www.who.int/publications/i/item/WHO2019-nCoV-vaccines-SAGE_recommendationSinovac-CoronaVac-CoronaVac-2021.1

Wu Q. et al. 2021. Evaluation of the safety profile of COVID-19 vaccines: a rapid review. BMC Medicine, 19(173):1-16: https://doi.org/10.1186/s12916-021-02059-5 